\title{
ABOUT SURKHANDARYA FOLKLORE
}

\author{
Ruzikul Boynazarovich Mustafokulov
}

Ph.D., Assistant Professor, Termez State University, Uzbekistan

\section{ABSTRACT}

This article summarizes the historical development of Sherabad baxshi school in Surkhandarya region, methods of performance, peculiarities of baxshi, a brief look at their creative activity, literary and artistic connection of baxshi schools of neighboring republics and regions, folklore written by folklorists in different years. analyzed.

KEYWORDS: - Folklore, ancient, history, original, folklore, folk songs, fairy tales, legends, epics, folk, sample, creative activity, baxshi, poet.

\section{INTRODUCTION}

The Uzbek folklore has an ancient history, and its achievements in the field of study, collection, publication and scientific research have been significant. The achievements of our folklore are well reflected in the generalized scientific articles published in connection with certain improvements in various monographs, textbooks and manuals. In particular, they are well generalized in the textbook "Oral folk oral poetic creativity" [1] prepared by folklorists K.Imamov, T.Mirzaev, B.Sarimsakov, O.Safarov.

There has also been a strong interest in the study of
Surkhandarya folklore. In this regard, folk songs, fairy tales, legends, seasonal songs, epics, national anthems and other types of samples are recorded from the mouths of the people who live and work here. We see this in the scientific researches of Hodi Zarif, M.Afzalov, M.Alaviya, T.Mirzaev, B.Sarimsakov, O.Safarov, A.Kahhorov, J.Eshonkulov, Sh.Turdimov, T.Turdiev, R.Mustafokulov and other scientists. .

In this regard, the scientific biographical essay of 0 . Sobirov about Umir Bakhshi Safarov, one of the representatives of the Sherabad school of baxshi, is noteworthy. [2] In it, the life of Umir Bakhshi, his creative activity, some epics included in the repertoire of Bakhshi are studied in a popular 
CURRENT RESEARCH JOURNAL OF PHILOLOGICAL SCIENCES 2(12):

183-189, December 2021

DOI: https://doi.org/10.37547/philological-crjps-02-12-35

ISSN 2767-3758

(C)2021 Master Journals

Crossref do

gil Google

Accepted21 $1^{\text {th }}$ December, 2021 \& Published $26^{\text {th }}$ December, 2021

scientific direction. In the first chapter of the book, entitled "Following in the footsteps of the Master", it is explained that Umir learned from the poet Sherna Bakhshi, followed in his footsteps, created various teams and skillfully continued the traditions of the teacher.

\section{Methods}

In the chapter "The word of the fathers - the eye of the mind" of the book, the range of themes and artistic skills of Umir's poets is studied. The chapter entitled "Heroes of our epic in the interpretation of baxshi" analyzes the variant features of the epics "Alpomish" and "Oyparcha" in the repertoire of Umir baxshi. Through comparative analysis, the scholar focuses on the skill aspects of Umir Bakhshi. In fact, if we compare the version of Umir Bakhshi with the epic "Alpomish" narrated by the poet Fozil, we will see some unique interpretations. The scientist observes that the fact that the Boysari decided to move from the ten thousand house bell Boys, the division of the nation disturbs the peace of every member of the tribe, making them anxious. The family quarrel between the brothers Boybori and Boysari, when the quarrel is discussed by the tribal elders, condemns Boysari's departure from Boysun, his beloved land. In the words of the elders of the tribe - their elders, their advisers - to the Boysari, the idea of the struggle for the unity of the tribe - the patriotic sentiments that were so important for their time - is put forward.

The scientist has analyzed a number of such differences. This emphasizes that Umir Bakhshi is a skilled performer with a unique talent. F. Alibaev in his article "El sevgan shoir". About the poet Umir was born in 1894 in the village of Gambir, Sherabad district, in a poor peasant family. According to him, his father Safar and his uncle Boynazar sang epics. He became a poet to Sherna Bakhshi. For six years, Umir studied the epics "Zondagar", "Golden
Pumpkin", "Balkhvon", "Mermaid", "Moon Piece", "Baghdad", "Alpomish", "Nurali", "Gorogly", "Ravshan" from his beloved teacher. and sang with interest for many years. He later wrote modern epics such as Karakum and Dastagul. [3]

"Sherabad Bakhshich School is large in terms of territory. The bakhshis of Surkhandarya, Kashkadarya, and sometimes southern Tajikistan were in constant contact with each other, and many of them are connected with Sherabad, "A. Qahhorov wrote.

From this point of view, the book "New Epics" [4] has played an important role in illuminating some of the traditions formed in this school. In particular, it states: "Reflecting on the Sherabad School of Poetry, it should be noted that this school has a special tradition in terms of teacher-student tradition, the distribution of students. That is, their geographical location today occupies a very large area. In particular, the Surkhandarya oasis includes the borders of Uzbeks living in the south of Tajikistan and Turkmenistan. This book is a source of new information in folklore based on the repertoire of folk singers of Kashkadarya and Surkhandarya. Based on the data collected by the scientist, he notes that the distribution of folklore genres in Kashkadarya and Surkhandarya regions is not uniform, and makes the following comments:

1. In the southern cities of Shakhrisabz, Karshi, Termez in Uzbekistan, small genres of folklore, mainly folk tales, are preserved.

2. In the villages of the Upper Mountains, for example, in the eastern part of the Kashkadarya - Miraqi, Rilon, in the south of the Gissar mountain range in the south, Vakhshivor, Sina in the upper part of the Boysun mountain range in the northeast of Surkhandarya, folk songs are especially preserved.

3. Poetry and epic poetry are preserved mainly 
CURRENT RESEARCH JOURNAL OF PHILOLOGICAL SCIENCES 2(12):

183-189, December 2021

DOI: https://doi.org/10.37547/philological-crjps-02-12-35

ISSN 2767-3758

(C)2021 Master Journals

\section{Crossref do) 81 Google}

Accepted21 ${ }^{\text {th }}$ December, 2021 \& Published $26^{\text {th }}$ December, 2021

among the population of Chirakchi, Guzar, Sherabad, Boysun, Angor and Jarqurghon regions, which are mainly engaged in farming in the hills and pastures.

\section{Results AND DISCUSSIONS}

For the first time in the book, a comprehensive analysis of the Sherabad school of epic poetry has been attempted. It contains some information about the poets who founded this school, in particular, Sherna Bakhshi.

As the book rightly points out, mature bakhshis such as Sherna, Khannazar, Mardonaqul, and Alim continued to pass on their traditions to the next generation. They especially traveled around the country, making the best talents their disciples and nurturing them. These bakhshis, in turn, cultivated more followers in the way of their masters. This tradition continues today.

A. Qahhorov's book provides good information about the new epics created by the bakhshis of this school. While analyzing the creation and distribution of these epics, the scholar paid special attention to their subject matter and ideology and direction.

For the first time in the book it is recommended to study Kashkadarya epics in two groups. According to the scientist, there are certain grounds for this. Because the epic poetry of Sherabad differs from the epics performed by the poets of Chirakchi and Kamashi with its tradition, ideology and perfection of artistic level. This is confirmed by the fact that the epics "Kelinoy" and "Karakum" created by Sherabad poets have not only variants, but also versions.

In his book, the folklorist also focuses on the issues of artistic mastery in the new epics created by the bakhshis of Surkhandarya and Kashkadarya. The research of the scientist shows that the plot structures, style of narration, means of dialogue, dialogue and monologues of such epics as "Norguloy", "Ulugoy", "Aysha", "Qizlarhon" and "Khonsuluv" differ from other new epics. In each of these epics, the individual characteristics of the bakhshi were clearly manifested. Abdiolim Ergashev confirms this idea in his book "Surkhandarya and Kashkadarya Schools of Epic" and says so.

There is no doubt that the epic Olanazar Olchinbek was formed in the process of asking Sherna or her father Berdinazar what he had to say about Ollanazar, asking his student to continue, or asking him to recite passages from all the epics. In any case, it was developed by several talented representatives of the Sherabad poetic school and stabilized as a work with a coherent plot and consistent composition." [5]

Good observations on the folklore of Surkhandarya are also available in the book of Ural Utaev, Otayor "Treasure equal to the world" [6]. The book consists of essays about modern bakhshis living in the republic, essays reflecting the current state of folklore, as well as literary ideas on the study, publication and promotion of bakhshis in various forms.

The essay considers Mardonaqul Avliyoqul oglu Sherna as the most talented representative of the school and provides important analytical comments on his work. Mardonaqul Bakhshi was orphaned at the age of eight, and at the age of sixteen Sherna Bakhshi became a student. He studied with the teacher for five years and sang dozens of epics, such as "Malla savdogar", "Oltin kaboq", "Sanam gavhar", "Nurali", "Olchinboy", "Alpomish". Bakhshi, known as "Surkhan Bulbuli", was imprisoned in 1937 as an enemy of the people, but was released in 1938 at 
CURRENT RESEARCH JOURNAL OF PHILOLOGICAL SCIENCES 2(12):

183-189, December 2021

DOI: https://doi.org/10.37547/philological-crjps-02-12-35

ISSN 2767-3758

(C)2021 Master Journals

Crossref do:

gil Google

Accepted21 $1^{\text {th }}$ December, 2021 \& Published 26 ${ }^{\text {th }}$ December, 2021

the request of the people. He also taught. It is noted in the essay that Umir Bakhshi Safar oglu, Yusuf Otagan oglu, Buri Ahmedov, Qiyom Choriev, Avaz Alimatov, Bazar Bakhshi, Karim Mallaev, Chorshanbi Rakhmatullaev raised dozens of students.

The essay on the late Almighty gives good information, including about his disciples. Among his students, Kadyr Bakhshi also mentions Boborahim Mamatmurodov (Markum) from Surkhandarya, and Shodmon Bakhshi Khojaberdiev. "Among my students, Shodmon Khojamberdiev from Surkhandarya entered the art of baxshi very early," said Kadyr baxshi. - Shodmon is distinguished by his eloquence, strong memory and the ability to create teams in the folk style.

The essay "Nightingale from Sayrob" in the book is dedicated to the work of the People's Bakhshi of Uzbekistan Shoberdi Boltaev. "One of the first teachers who taught him was Khushvaqt Mardonakulov. He was the first to warn Shoberdi of the mysteries of the epic. Later, Shoberdi became a friend and student of the late Qadir Bakhshi Rahim's son and further improved his storytelling skills, "the essay reads.

The film "Competitions, Problems" summarizes and discusses the participation of students in the competitions held throughout the country and the experience gained in these competitions. Among the winners of the competitions are Khushbok Bakhshi, Shoberdi Bakhshi, Boborahim Bakhshi and Shodmon Bakhshi from Surkhandarya.

The celebration of the 1000th anniversary of the epic "Alpomish" in our country is an expression of deep respect for the national epic, its values, history and cultural heritage. As the First President of our country IA Karimov said in his speeches at the ceremony, in fact, if the ancient and reliable history of our people is an endless epic, "Alpomish" is the epitome of this epic. In this classic play, the noble qualities of our people, such as tolerance, perseverance, nobility, which survived the storms of history, life and death tests and did not lose their identity, are reflected. "[7] Khushvaqt Mardonakulov, researchers, creators, artists have prepared gifts worthy of this date. For example, the collection "Alpomish - Uzbek folk heroic epic" published by "Fan" contains articles on this work, reflecting the scientific views of folklore scholars of the republic.

The collection opens with an article by Professor Tora Mirzaev entitled "Epic of Alpomish, its versions and variants." The article is devoted to the analysis of issues related to the study, writing and publication of the epic "Alpomish". It rightly emphasizes that the epic "Alpomish" in all its aspects, along with such great folk epics as "Iliad", "Odessia", "Mahobkhorat", "Ramayana", "Shohnoma", "Manas". The article also focuses on the issues raised in the decision of the government to celebrate the 1000th anniversary of the epic "Alpomish", the history of the epic, the work of scientists and researchers who have dedicated themselves to its writing and promotion. This will help readers to enrich their knowledge of the epic and get the right attitude and direction.

The collection also includes an article entitled "The main motives of the epic" Alpomish "by the famous scientist, the founder of Uzbek folklore Hodi Zarif" [8]. This article is based on the scientist's articles published in the 1st issue of the magazine "Sharq Yulduzi" in 1957 and in the collection "Ob epose Alpomish" published in 1959. It is known that in 1952, A.Abdunabiev and A.Stepanov published an article in the 2nd issue of the magazine "Zvezda Vostoka" entitled "Under the flag of the people" and attacked the friend, slandering his researchers. In this regard, a discussion was held in the Writers' 
CURRENT RESEARCH JOURNAL OF PHILOLOGICAL SCIENCES 2(12):

183-189, December 2021

DOI: https://doi.org/10.37547/philological-crjps-02-12-35

ISSN 2767-3758

(C)2021 Master Journals

\section{Crossref do) 81 Google}

Accepted21 ${ }^{\text {th }}$ December, 2021 \& Published $26^{\text {th }}$ December, 2021

Union of Uzbekistan, in which supporters of the attack were found. Hadi Zarif was one of the scholars who fought against such views and exposed their attacks on the basis of irrefutable evidence. In this article, these views of the teacher are fully expressed.

There is also an epic by V. Zhirmunsky about "Alpomish" and an article by Homer "Odessia". This scientific article is also interesting for its richness in analysis. In general, the scholar did not care about the slanders and attacks mentioned above, and continued to study the epic "Alpomish" for the rest of his life. In this article, he seems to have come to an important conclusion by comparing this epic with the epic heritage of the peoples of the world. In particular, the scholar concludes from a comparative analysis that vital data on the many similarities between Odessia and Alpomish allow us to cross-examine the interrelationships of ancient and Central Asian cultures, or more precisely, the influence of Eastern culture on Greek culture.

Professor M.Juraev's article entitled "Mythological images in the epic" Alpomish "" is also of great interest to readers with its unique analysis. The author of the article also mentions the names Boysun, Boybori, Boysari. According to the scholar, "The term Boysun is an epic name, based on its historical roots, based on the mythological notions of the ancient Turks about the Ashina clan, who worshiped the wolf tattoo." He also concludes that "the term Boybori was in fact the name of one of the ancient Turkic tribes and must have later become an epic name" [9].

Thanks to the decision on the 1000th anniversary of the epic and the events associated with it, the first volume of the book "Alpomishnoma" "Surkhandarya interpretation" [10]. This book, written by Professor M. Murodov and Associate Professor A. Ergashev, contains a number of innovations. It describes the creative meetings, scientific-practical conferences, conversations, competitions held on the occasion of the 1000th anniversary of the epic. The work of the international scientific expedition "In the footsteps of Alpomish" was discussed. In particular, in the Boysun and Sherabad districts of Surkhandarya, the first chapter of the book is devoted to the names of places associated with the epic "Alpomish", folk legends, bakhshis, local opinions, fragments from diaries and diaries, etc.

The second chapter of the book is called "Surkhan's interpretation of Alpomish". It analyzes the study of the epic of the oasis, gives information about the bakhshis living here, the epics "Oysanam", "Kelinoy", "Gupponoy", "Eshqora and Dostqora", "Jayhun maston" and others.

In general, more than 200 epics have been written by Surkhandarya bakhshis.

This section provides extensive information about Surkhandarya epic schools. There is information about the existence of a number of epics and separate series in the repertoire of bakhshis of Surkhandarya region, which are not found in other schools of epic poetry of the country, enriching the Uzbek and all-Turkic epics. The author's comments on the series "Alpomish", in particular, the comments and some analyzes on the formation of the lineage of Alpomish, including the unpublished epics "Beva Barchin", "Yodgor", "Yulchiboy" and "Shomurod" are also interesting. The book contains excerpts from the epic "Alpomish" written by Kara Bakhshi, Khushvaqt Bakhshi, Chorsha Bakhshi. Excerpts from the epics of the People's Bakhshi of Uzbekistan Abdunazar Bakhshi "Tursun Mergan", Chorsha Bakhshi "Yodgor", Qahhor Bakhshi "Beva Barchin" serve to give an idea of this series. 
CURRENT RESEARCH JOURNAL OF PHILOLOGICAL SCIENCES 2(12):

183-189, December 2021

DOI: https://doi.org/10.37547/philological-crjps-02-12-35

ISSN 2767-3758

(C)2021 Master Journals

Crossref doi

gil Google

Accepted21 $1^{\text {th }}$ December, 2021 \& Published $26^{\text {th }}$ December, 2021

In the third chapter of the book there is a family tree of the epic series "Alpomish", Boysun (Kofirun), Beshkotan baxshi schools, Sherna students, Shernazar Berdinazar oglu family family tree, Umir poet Safar oglu's teacher-student tree, Kara bakhshi's master book evidences of meritorious research and fruitful work.

The roots of the Sherabad school of epic poetry are deep and strong, energetic, lifelong. Among the descendants of this school are ten people's bakhshis of Uzbekistan Shoberdi bakhshi Boltaev, Boborahim bakhshi Mamatmurodov (deceased), Abdunazar bakhshi Poyonov, Khushbok bakhshi Mardonakulov, Qora bakhshi, Chori bakhshi, Rasul bakhshi Umirov, Shodmon bakhshi Khojamberdiev, Bakhshikul and Togaev. are becoming. The creative skills of their companions Zulhumor Bakhshi Shernazar qizi, Jovli Bakhshi, Safar Bakhshi, Omon Bakhshi, Ural Bakhshi Muhammad Bakhshi are increasing year by year and a number of epics have been written from them and they have reached the hands of students.

In the tradition of Sherabad baxshi school, among the middle-level baxshis, such baxmis as Kholmurod baxshi, Abdusalom baxshi, Panji baxshi, Toran baxshi, Gulboy baxshi, Qahhor baxshi, Alimardon baxshi, Shamsiddin baxshi, Roziqul baxshi, Kenja baxshi, Ravshan baxshi continue to play ancient melodies. Along with them, young bakhshis Norali bakhshi, Ilhom bakhshi, Akram bakhshi, Sabir bakhshi, Zokir bakhshi, Sherali bakhshi are also boldly looking for a place in the network of the period, holding words in their hands, reciting epics and terms.

Today, the grandchildren, great-grandchildren and great-grandchildren of the founders of the Sherabad School of Poetry are the People's Bakhshi of Uzbekistan: Khushbok Bakhshi Mardonakulov, Chori Bakhshi, Kara Bakhshi, Rasul Bakhshi Umirov,
Shoberdi Bakhshi Boltaev, Shodmon Bakhshi Khojamberdiev and dozens of their students. They create traditional and modern epics and present them to our friendly people. Based on this information, it is safe to say that Surkhan oasis is the land of bakhshis. The number of fans of Bakhshi in foreign countries is growing. Their fans are innumerable. Our next task is to collect its variants and versions, to collect, analyze and publish new information that is currently silent in the land of bakhshis, in the drum notebook.

During the years of independence, more than 50 collections of epics and poems have been written from the heirs of the Sherabad baxshi school.

President of the Republic Sh. On the recommendation of Mirziyoyev, in 2017, as part of a recreation center on the shores of the Amu Darya in Termez, a "Creative Center for Bakhshi" was opened in Surkhandarya. Young bakhshis are improving their skills in the school circle. Representatives of Sherabad baxshi school, people's baxshi of Uzbekistan Kara baxshi, Chori baxshi, Rasul baxshi Umirovs, Shoberdi baxshi, Abdunazar baxshi, Shodmon baxshi, Bakhtiyor baxshi, Muhammadi baxshi, who have gained the attention of the people and the country, teach them their experience and skills, narration performances.

The decision of the President of the Republic of Uzbekistan on November 1 of this year to hold the International Festival of the art of baxshi every two years is another proof of the care for the work of our baxshis.

Thus, the best traditions of the Sherabad baxshi school are successfully continued by the Surkhan oasis bakhshis, whose repertoire is enriched with new traditional and modern epics and ensembles. 
CURRENT RESEARCH JOURNAL OF PHILOLOGICAL SCIENCES 2(12):

183-189, December 2021

DOI: https://doi.org/10.37547/philological-crjps-02-12-35

ISSN 2767-3758

(C2021 Master Journals

Crossref do

Accepted21 ${ }^{\text {th }}$ December, 2021 \& Published $26^{\text {th }}$ December, 2021

1. Sobirov O. Umir poet Safarov T., "Fan”, 1982. 10-p.

2. Imamov K., Mirzaev T., Sarimsakov B., Safarov O Uzbek folk oral poetry, T., "Teacher" 1990. pp. 23-42.

3. Aliboev F. Surkhandarya region newspaper "Mehnat Zafari" February 12, 1993.

4. Qahhorov A. New Epics, T., "Science," 1998.

5. Abdi Olim Ergashev. KashkadaryaSurkhandarya epic, Tashkent Academy of Sciences of the Republic of Uzbekistan "fan" publishing house 2008

6. Otaev O., Otayor. A Treasure Peer to the World, T., The Writer, 1994.

7. "Alpomish" - Uzbek folk heroic epic. T., "Fan", 1999. 24-156-p.

8. Xodi Zarifov. The main motives of the Alpomish epic "Teacher" Publishing House Tashkent-1980

9. Juraev M Uzbek folk heroic epic T., "Science", 1999. 147 p.

10. Murodov M., Ergashev A., Alpomishnoma, T., "Labor", 1999.

11. Mustafoqulov R. People's pedagogical source "Jayhun" publishing house - Termez-1996.

12. Yakibova Dilorom Sharifovna. Improvement of Creative Attention of Teachers in Technology. International Journal of Science and Research (IJSR). India. 2020

13. Yakibova Dilorom Sharifovna. Implementation Bases of Using Multimedia Technologies In The Organization Of Educational Process. THINK INDIA (Quarterly Journal). New Delhi, 110086, India. 5898-5904.

14. Якибова Д. Ш. Творческий подход к формированию рабочей силы у учащихся начальных классов //доктора/кандидата наук предлагаем вступить в редакционную коллегию журнала (подробности на сайте). - 2019. - С. 158.
15. Якибова Д. Ш. Обучать учеников начальной школы, участвуя в связанных с работой мероприятиях и клубах //Научные горизонты. - 2019. - №. 4. - С. 152-157.

16. Makhmaraimova S. T., Yakibova D. S. SPEECH DEVELOPMENT IN LESSONS OF PHYSICAL CULTURE BY MEANS OF COMMUNICATIVE GAMES //Scientific Bulletin of Namangan State University. - 2019. - T. 1. - №. 9. - C. 187-193.

17. Якибов Ш. Х. Х. Х., Якибова Д. Ш. ИЗУЧЕНИЕ ВОЗМОЖНОСТЕЙ ВНЕКЛАССНОЙ РАБОТЫ С УЧАЩИМИСЯ В ФОРМИРОВАНИИ БУДУЩИХ ПРОФЕССИОНАЛЬНЫХ НАВЫКОВ //доктора/кандидата наук предлагаем вступить в редакционную коллегию журнала (подробности на сайте). - 2018. С. 364. 